\title{
SORPTION OF MALACHITE GREEN (MG) BY CASSAVA STEM BIOCHAR (CSB): KINETIC AND ISOTHERM STUDIES
}

\author{
M. K. Z. M. Zaid ${ }^{1}$, N. A. Jamion' ${ }^{1}$, Q. Omar ${ }^{2}$ and S. K. Yong ${ }^{3, *}$ \\ ${ }^{1}$ Faculty of Applied Sciences, UniversitiTeknologi MARA, 40450 Shah Alam, Selangor, \\ Malaysia \\ ${ }^{2}$ Faculty of Applied Sciences, UniversitiTeknologi MARA, 72000 Kuala Pilah, Negeri \\ Sembilan, Malaysia \\ ${ }^{3}$ Centre of Foundation Studies, UniversitiTeknologi MARA, 43800 Dengkil, Selangor, \\ Malaysia
}

Published online: 10 November 2017

\begin{abstract}
Cassava stem biochar (CSB) was produced by pyrolyzing CS at $500^{\circ} \mathrm{C}$ for 2 hours at nitrogen environment. Proximate and ultimate analyses were conducted on CS and CSB. Batch sorption experiment on synthetic MG wastewater was optimized for the sorbent dosage, $\mathrm{MG}$ solution $\mathrm{pH}$ and contact time. Sorption data was analysedwith linearized sorption kinetic and linearized isotherm models. Pyrolysis of CS produced carbon-rich and stable CSB with a yield of $11.94 \%$. The optimum sorption sorbent dosage, MG solution $\mathrm{pH}$ and contact time are $1.67 \mathrm{~g} / \mathrm{L},>\mathrm{pH} 7.4$ and 10 minutes respectively. The sorption of MG by CSB was best described by the pseudo-second-order kinetic model and the Langmuir isotherm model. The Langmuir sorption capacity of CSB was $40.5 \mathrm{mg} / \mathrm{g}$. Monolayer of MG molecules formed chemical bonds on the homogenous surface of CSB.
\end{abstract}

Keywords: Manihotesculenta Crantz; charcoal; black carbon; adsorption.

Author Correspondence, e-mail: yongsk@salam.uitm.edu.my

doi: http://dx.doi.org/10.4314/jfas.v9i6s.22 


\section{INTRODUCTION}

Dyes are organic or inorganic molecules used in large mount in the textile industry, producing a considerable amount of coloured wastewater in the waterways [1]. Malachite green is one of the common textile dyes also used in the aquaculture for controlling parasite, fungus and protozoan infections on aquatic organisms[2]. However, MG is highly toxic to aquatic fauna, flora and human beings. Moreover, MG may also increase the level of Chemical Oxygen Demand in wastewater and decrease Dissolved Oxygen in aquatic environments [3]. Hence, its removal from the effluent streams is highly needed [2].

Conventionally, dyes may be managed by chemical oxidation. However, these methods of wastewater treatment may not be feasible in long run due to the rising cost of chemicals and the possibility of creating secondary pollutant. Removal of MG from water treatment may be a cheaper option, especially when utilizing waste biomass [4-5]. To enhance the performance of biomass sorbent, dry carbonization or pyrolysis produces carbon materials called biochar that possesses large surface area due to its porous structure. The benefit of using waste biomass for biochar production compared to other types of biomass is that it is cost-effective $[6]$.

Cassava (ManihotesculentaCrantz) is a food crop that has high biomass yield and is resilient to environmental stresses. Apart from the tuber peel, the cassava stem (CS) is the major waste biomass produced from harvesting this crop and most are abandoned or burned on the fields. Only $10-20 \%$ of CS are used for propagation [7]. Cassava stem may be converted to biochar for sorption of MG. To the best of our knowledge, cassava stem based carbon has been produced and studied but none has been focussed on its sorption of pollutants from aqueous phase. The objectives of this study are:

i. To characterize the physical and chemical properties of CS and CSB.

ii. To determine the optimum sorption parameters (i.e., such as $\mathrm{pH}$, contact time, sorbent dosage and initial concentration) of CSB for the removal of MG from aqueous system.

iii. To identify the maximum sorption capacity and sorption mechanism of MG by CSB using isotherm and kinetic models. 


\section{RESULTS AND DISCUSSION}

\subsection{Proximate Analysis of CS}

Fig. 1 shows the percentages of moisture, volatile, fixed carbon and ash in CS. The moisture content of CS was $53.41 \%$, the volatile matter content was $32.84 \%$, the fixed carbon content was $11.94 \%$ and the ash content was $1.82 \%$. Cassava stem consists primarily moisture and volatile contents. The fixed carbon and ash contents were similar to those reported by [8].
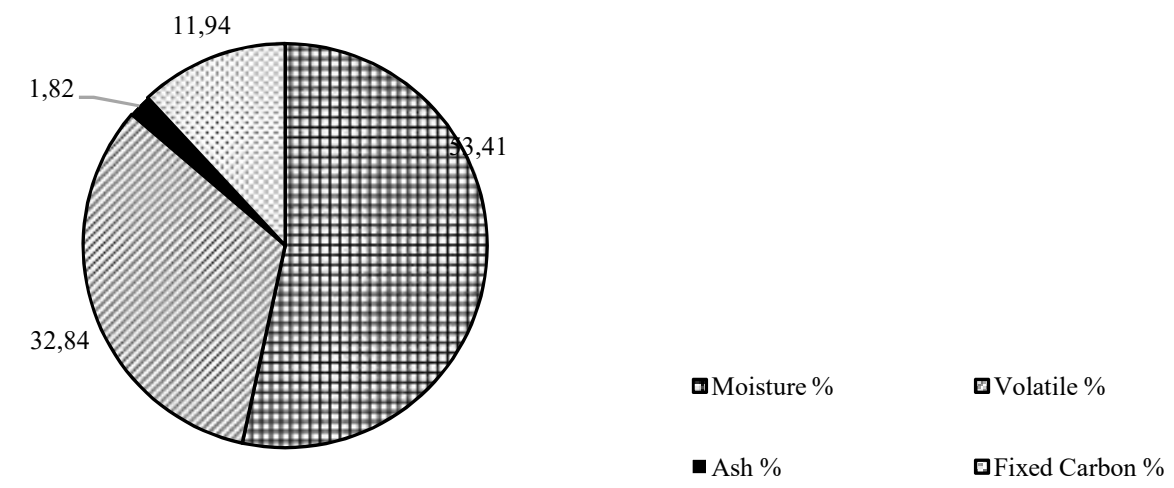

Fig.1. The percentages of moisture, volatile, ash and fixed carbon for CS

\subsection{Ultimate Analysis for CS and CSB}

Table 1 shows the percentages of C, H, N, O and S for CS and CSB. Pyrolysis process increased the percentage for $\mathrm{C}$, but decreased that of $\mathrm{O}$. The high $\mathrm{C} / \mathrm{O}$ ratio for $\mathrm{CSB}$ implies a high stability [9]. Cassava stem contains no $\mathrm{N}$ nor $\mathrm{S}$. Therefore, pyrolysis of CS will not release environmentally non-friendly gaseous emission, such as $\mathrm{NO}_{\mathrm{x}}$ and $\mathrm{SO}_{2}$.

Table 1.Percentages of C, O, H, N and S for CS and CSB

\begin{tabular}{ccc}
\hline Element & \multicolumn{3}{c}{ Percentage $(\% \mathbf{w} / \mathbf{w})$} \\
& CS & CSB \\
\hline $\mathrm{C}$ & 44.78 & 74.45 \\
$\mathrm{O}$ & 49.66 & 23.38 \\
$\mathrm{H}$ & 5.56 & 2.17 \\
$\mathrm{~N}$ & 0 & 0 \\
$\mathrm{~S}$ & 0 & 0 \\
\hline
\end{tabular}




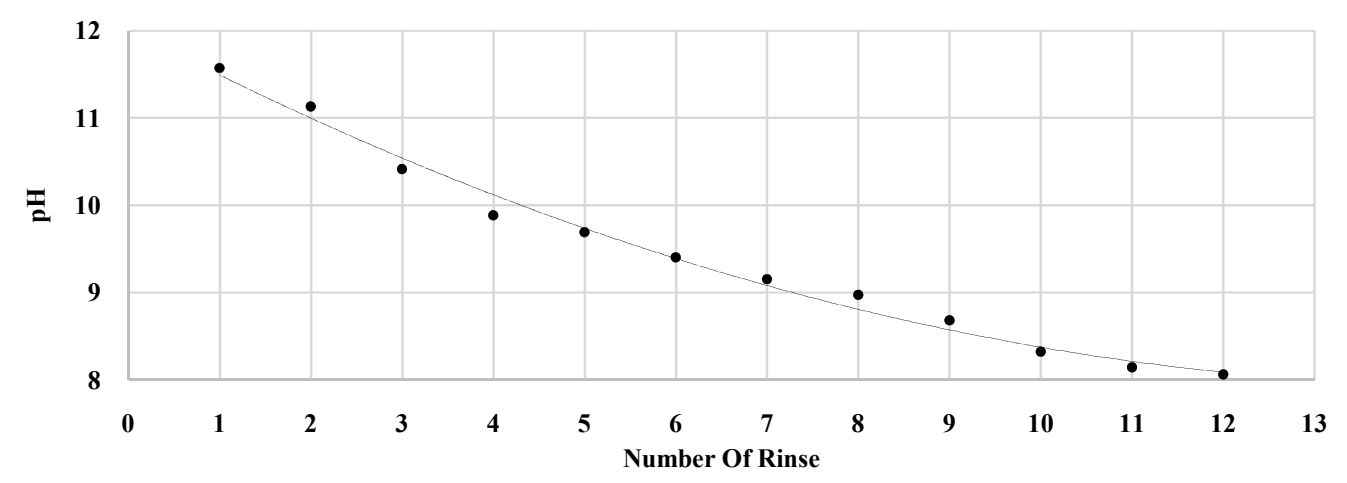

Fig.2.pH values for CSB as a function of rinsing frequency

Fig. 2 shows the $\mathrm{pH}$ of CSB as a function of rinsing frequency. The high pyrolysis temperature has cause high $\mathrm{pH}$ of CSB [10]. The initial $\mathrm{pH}$ value of the quenched CSB (i.e., 11.57) decreased (to about $\mathrm{pH}$ 8) with increasing frequency of rinsing. The ash in the quenched CSB is alkaline and its removal from rinsing with deionized water has gradually decrease the $\mathrm{pH}$ value of CSB.

\subsection{Optimization of Batch Sorption Parameters}

Fig. 3 shows the removal percentage (\%) of MG from the aqueous solutions as a function of CSB sorbent dosage $(\mathrm{g} / \mathrm{L})$. The removal percentage increased to reach the plateau at $90.4 \% \mathrm{MG}$ removal, and at $1.67 \mathrm{~g} / \mathrm{L}$ of CSB dosage. After that, there is no significant difference in the removal percentage of MG. The upward trend of the percentage removal is due to the increase of available surface area from higher CSB sorbent dosage [11]. The slight increase of MG removal percentage at an elevated CSB dose (i.e., $\geq 1.67 \mathrm{~g} / \mathrm{L}$ ) may be due to the competition among sorbent molecules and the splits present in the concentration gradient [12-13]. 


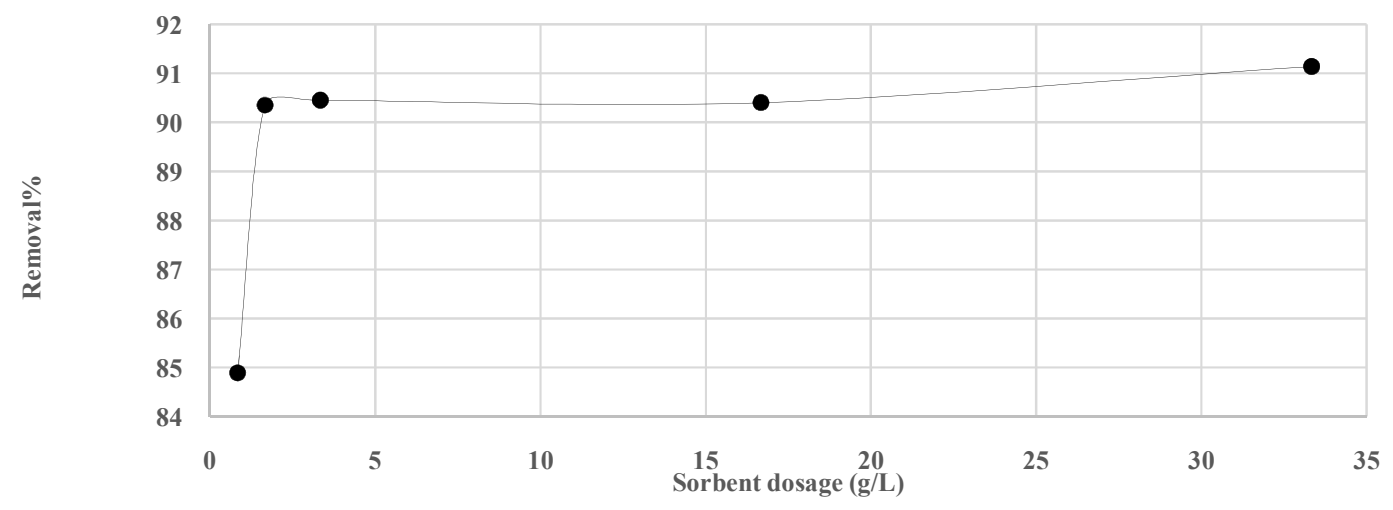

Fig.3. Removal percentage (\%) of MG from aqueous solution as a function of CSB sorbent dosage $(\mathrm{g} / \mathrm{L})$ [Constant variables: agitation $(100 \mathrm{rpm})$, contact time (10 minutes), initial concentration $(50 \mathrm{ppm})]$

The sorption capacity of CSB, $\mathrm{q}_{\mathrm{t}}(\mathrm{mg} / \mathrm{g})$ as a function of contact time (minute) was illustrated in Fig.4. Rapid uptake of MG occurred from the beginning until the $10^{\text {th }}$ minute, whereby the sorption capacity was $23.7 \mathrm{mg} / \mathrm{g}$. Then, the $\mathrm{q}_{\mathrm{t}}$ value increased slightly until $26.8 \mathrm{mg} / \mathrm{g}$ at the $60^{\text {th }}$ minute. At the beginning of the experiment, free binding sites were present on the surface of CSB. But after the $10^{\text {th }}$ minute, the surface of CSB may have been saturated with MC. The optimum contact time for sorption of $\mathrm{MG}$ from aqueous solution is 10 minutes.

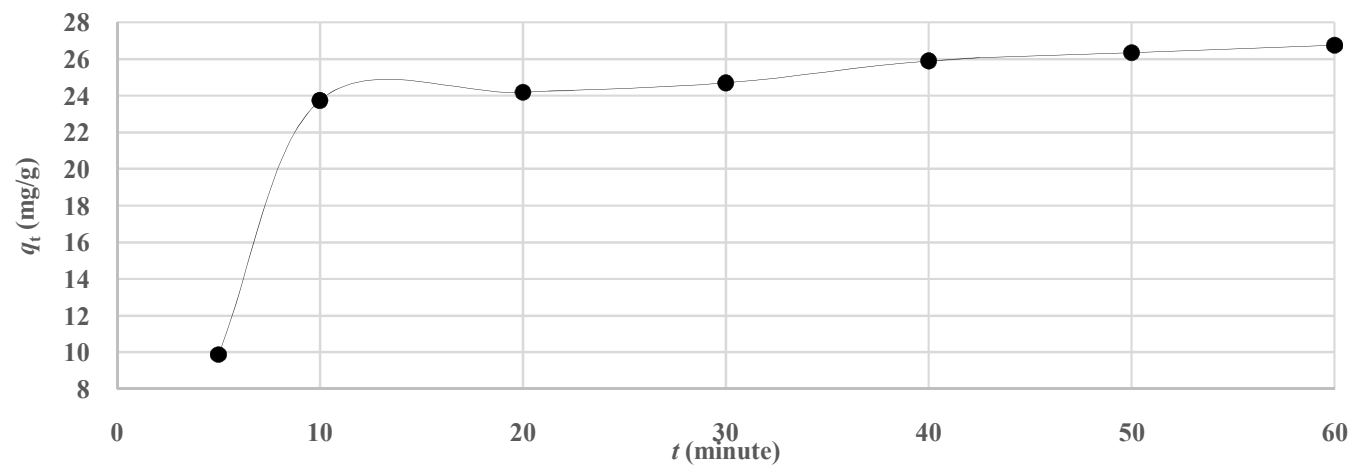

Fig.4. Sorption capacity of CSB, $\mathrm{q}_{\mathrm{t}}(\mathrm{mg} / \mathrm{g})$ as a function of contact time, $\mathrm{t}$ (minute) [Constant variables: CSB sorbent dosage $(1.67 \mathrm{~g} / \mathrm{L})$, agitation $(100 \mathrm{rpm})$, initial MG concentration $(50$ $\mathrm{mg} / \mathrm{L})]$

Generally, the $\mathrm{pH}$ of MG solution was increased by $0.5-2.0 \mathrm{pH}$ unit upon contact with CSB. The initial, unadjusted $\mathrm{pH}$ for MG solution (i.e., 3.9) was increased to 7.2 and 8.2 after agitation with CSB for 5 and 120 minutes respectively. Fig.5 shows the sorption capacity of CSB, $\mathrm{q}_{\mathrm{t}}$ $(\mathrm{mg} / \mathrm{g})$ as a function of equilibrium MG solution $\mathrm{pH}$. The $\mathrm{q}_{\mathrm{t}}$ values increased rapidly from 12.2 
to $26.4 \mathrm{mg} / \mathrm{g}$ when the equilibrium $\mathrm{pH}$ of the $\mathrm{MG}$ solution increased from 6.2 to 7.4 respectively. The $\mathrm{q}_{\mathrm{t}}$ values were increased slightly between $\mathrm{pH} 7.4$ and $\mathrm{pH} 9.0$. Low amount of $\mathrm{MG}$ was adsorbed onto $\mathrm{CSB}$ at $<\mathrm{pH}$ 7.4. The excessive amount of hydronium ion in acidic $\mathrm{MG}$ solution may cause protonation of MG and functional groups on CSB surface. Malachite green molecules may form positively-charge MG derivatives and remain soluble due to the electrostatic repulsion [14]. Moreover, the hydronium ion may compete with the positively-charged MG derivative for sorption sites on CSB surface [15]. The protonation of CSB surface sites may cause deactivation of the carboxylate and phenolate groups [16-17]. However, at high MG solution pH (i.e., >7.4), MG molecules were deprotonated to form neutrally-charged MG derivative (i.e., carbinol) [18]. Consequently, electrostatic repulsion between the MG and the negatively charged surface of CSB decreased, resulting in the increase of $\mathrm{q}_{\mathrm{t}}$ values [19].

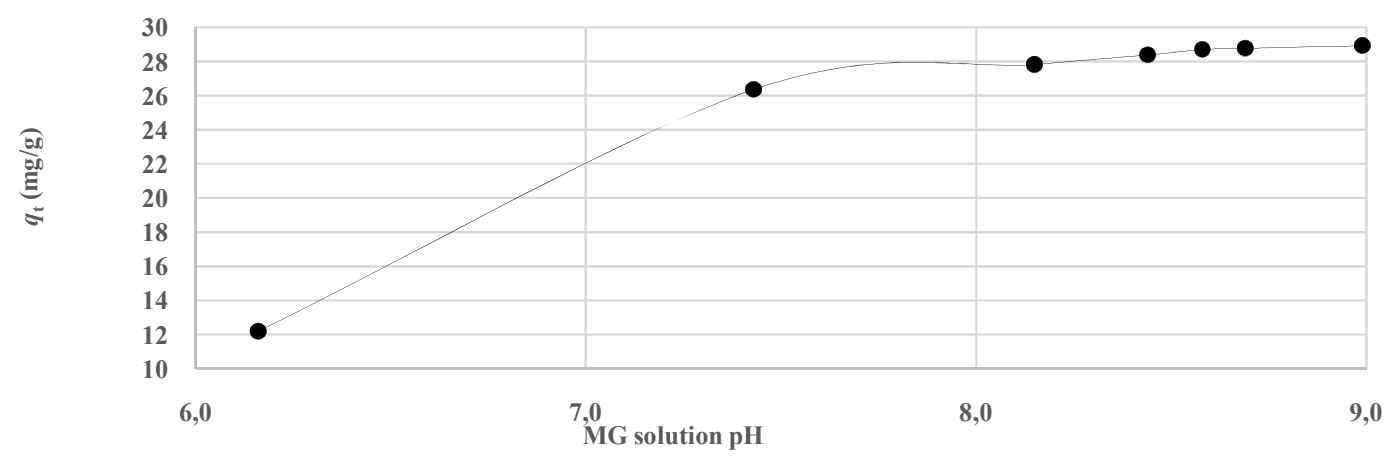

Fig.5.Sorption capacity of CSB, $\mathrm{q}_{\mathrm{t}}(\mathrm{mg} / \mathrm{g})$ as a function of equilibrium $\mathrm{MG}$ solution $\mathrm{pH}$ [Constant variables: CSB sorbent dosage (1.67 g/L), contact time (10 minutes), agitation (100 $\mathrm{rpm})$, initial $\mathrm{MG}$ concentration $(50 \mathrm{mg} / \mathrm{L})]$

\subsection{Sorption Kinetic and Isotherm}

Table 2 shows the parameters for pseudo-first-order and pseudo-second-order kinetic models for sorption of MG by CSB. The sorption kinetic were best described by the pseudo-second-order model $\left(\mathrm{R}^{2}=0.988\right)$, compare to the pseudo-first-order model $\left(\mathrm{R}^{2}=0.867\right)$. This indicates that the rate-limiting step for sorption of MG was possibly controlled by a chemical process on the CSB surface [20]. 
Table 2. Parameters of pseudo-first-order and pseudo-second-order kinetic models for sorption of MG by CSB

\begin{tabular}{ccc}
\hline Model & \multicolumn{2}{c}{ Parameter } \\
\hline Pseudo-first-order & $\mathrm{q}_{\mathrm{e}(\exp )}\left(\mathrm{mg} \mathrm{g}^{-1}\right)$ & 26.8 \\
& $\mathrm{q}_{\mathrm{e}(\mathrm{cal})}\left(\mathrm{mg} \mathrm{g}^{-1}\right)$ & 12.2 \\
& $\mathrm{k}_{1}\left(\mathrm{~min}^{-1}\right)$ & 0.0677 \\
& $\mathrm{R}^{2}$ & 0.867 \\
Pseudo-second-order & $\mathrm{q}_{\mathrm{e}(\mathrm{exp})}\left(\mathrm{mg} \mathrm{g}^{-1}\right)$ & 26.8 \\
& $\mathrm{q}_{\mathrm{e}(\mathrm{cal})}\left(\mathrm{mg} \mathrm{g}^{-1}\right)$ & 29.6 \\
& $\mathrm{k}_{2}\left(\mathrm{~g} \mathrm{mg}^{-1} \mathrm{~min}^{-1}\right)$ & 0.0057 \\
& $\mathrm{R}^{2}$ & 0.988 \\
\hline
\end{tabular}

Fig.6 shows the plot for $\mathrm{q}_{\mathrm{t}}$ value $(\mathrm{mg} / \mathrm{g})$ as a function of equilibrium $\mathrm{MG}$ concentration $(\mathrm{mg} / \mathrm{L})$. The $\mathrm{q}_{t}$ value for CSB increased with increasing $\mathrm{C}_{\mathrm{e}}$ value. In general, $\mathrm{q}_{\mathrm{t}}$ values increased with increasing $\mathrm{C}_{\mathrm{e}}$ values. High initial concentration for MG may have contributed toa high driving force for the transfer of MG molecule onto CSB surface[21].

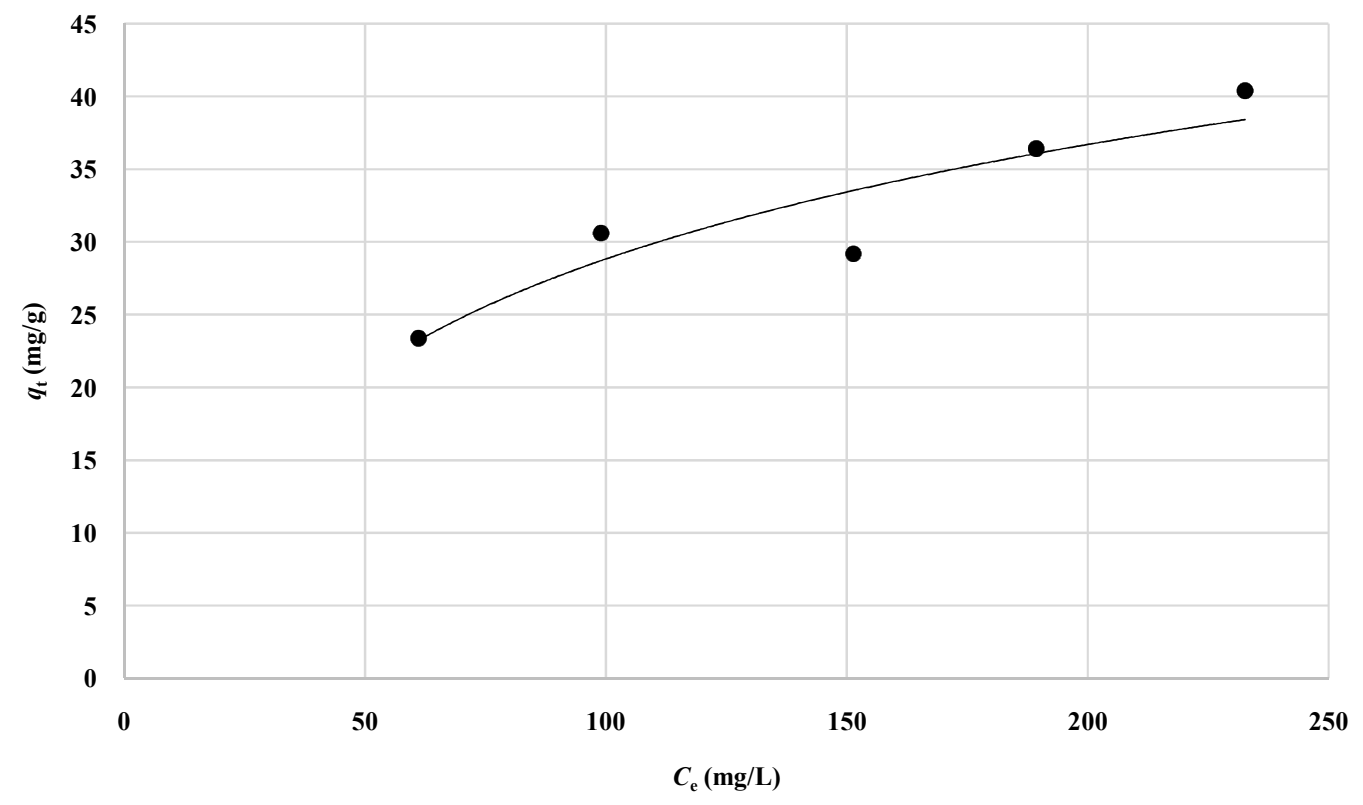

Fig.6. Sorption capacity of CSB, $\mathrm{q}_{t}(\mathrm{mg} / \mathrm{g})$ as a function of equilibrium $\mathrm{MG}$ concentration, $\mathrm{C}_{\mathrm{e}}$ $(\mathrm{mg} / \mathrm{L})$ [Constant variables: CSB sorbent dosage (1.67 g/L), contact time (10 minutes), agitation $(100 \mathrm{rpm})]$ 
Table 3 shows parameters of Langmuir and Freundlich isotherm models for sorption of MG by CSB. The sorption data was best described by the Langmuir isotherm $\left(\mathrm{R}^{2}=1.00\right)$, compare to the Freundlich isotherm $\left(\mathrm{R}^{2}=0.284\right)$. This indicates that sorption occurred where $\mathrm{MG}$ molecules occupy one active site on the homogeneous surface of CSB [22]. The value of $R_{L}$ is $1.61 \times 10^{-15}$, indicating that the sorption of MG by CSB is unfavourable.

Table 4 shows the sorption capacities of MG by bagasse fly ash, walnut shell, Oil palm trunk fibre, Casuarinaequsetifolia needle, chitin and CSB. Sorption capacity of CSB is comparable to that of bagasse fly ash and higher than chitin but is still lower than those of walnut shell, Oil palm trunk fibre, Casuarinaequsetifolia needle. However, CSB is a stable, carbon-rich sorbent. Even with an inferior sorption capacity for MG, CSB and may be more resistant to degradation and is more suitable to be regenerated and reused.

Table 3. Parameters of Langmuir and Freundlich isotherm models for sorption of MG by

\begin{tabular}{ccc}
\multicolumn{3}{c}{ CSB } \\
\hline Model & \multicolumn{2}{c}{ Parameter } \\
\hline Langmuir & $\mathrm{K}_{\mathrm{L}}\left(\mathrm{L} \mathrm{mg}^{-1}\right)$ & $1.24 \times 10^{13}$ \\
& $\mathrm{q}_{\mathrm{MAX}}\left(\mathrm{mg} \mathrm{g}^{-1}\right)$ & 40.5 \\
& $\mathrm{R}^{2}$ & 1.00 \\
Freundlich & $\mathrm{R}$ & $1.61 \times 10^{-15}$ \\
& $\mathrm{n}$ & 14.6 \\
& $\mathrm{~K}_{\mathrm{F}}\left(\mathrm{mg} \mathrm{g}^{-1}\right)$ & 22.9 \\
& $\mathrm{R}^{2}$ & 0.284 \\
\hline
\end{tabular}


Table 4. Langmuir sorption capacities forMB by CSB andothervarious sorbent materials

\begin{tabular}{ccc}
\hline Sorbent & Langmuir Sorption Capacity $\left(\mathbf{m g ~ g}^{\mathbf{- 1}}\right)$ & Reference \\
\hline Bagasse fly ash & 42.2 & {$[23]$} \\
Walnut shell & 90.8 & {$[24]$} \\
Oil palm trunk fibre & 149.3 & {$[25]$} \\
Casuarinaequsetifolia needle & 77.6 & {$[26]$} \\
Chitin & 29.6 & {$[27]$} \\
CSB & $\mathbf{4 0 . 5}$ & This study \\
\hline
\end{tabular}

\section{EXPERIMENTAL}

\subsection{Sampling of CS and Preparation of CSB}

Cassava stem with an average diameter of $5 \mathrm{~cm}$ was collected at KampungDamai, Kuang, Selangor. Cassava stem was sun-dried for 7 days, and oven-dried further in the oven at $70^{\circ} \mathrm{C}$ for 5 days. Then, the septum was removed and the bark was crushed, pulverized and sieved to $\leq 2 \mathrm{~mm}$ of particle diameter. For the preparation of CSB, pyrolysis of CS was conducted using a muffle furnace at $500^{\circ} \mathrm{C}$ in nitrogen gas ambient for 2 hours [28]. Hot CSB was quenched and rinsed thoroughly with deionized water to remove ash. Then, it was oven-dried at $100^{\circ} \mathrm{C}$ for 24 hours, and sieved to particle size of $\leq 150 \mu \mathrm{m}$.

\subsection{Characterization of CS and CSB}

Proximate analysis $(\% \mathrm{w} / \mathrm{w})$ was conducted by gravimetric method to determine the contents of moisture, ash, volatile matter and fixed carbon for CSB [29]. The weights of fresh and oven-dried CS were used to determine moisture content. Ash content was determined from combustion of the oven-dried $\mathrm{CS}$ at $750^{\circ} \mathrm{C}$ for 1 hour using a furnace to produce ash, fixed carbon was determined from $\mathrm{W}_{\mathrm{c}}$ and volatile matter was determined by difference. The $\mathrm{pH}$ for CSB was determined using a calibrated $\mathrm{pH}$ meter. Ultimate analysis was conducted using CHNS elemental analyzer (Thermofinnigan Flash EA2000, UK) and the oxygen was calculated by difference.

\subsection{Optimization of Batch Sorption Parameter}

Malachite green stock solution $(100 \mathrm{mg} / \mathrm{L})$ was prepared by diluting MG chloride salts with deionized water, and stored at $4^{\circ} \mathrm{C}$ in an amber reagent bottle. The stock MG solution was 
diluted to $50 \mathrm{mg} / \mathrm{L}$ and was used for all sorption optimization experiments except for sorption isotherms. All solution was filtered using centrifuged at $40000 \mathrm{rpm}$ for 30 minutes and filtered with $0.45 \mu \mathrm{m}$ millipore syringe filter and the concentration of residual MG solution was analyzed by colorimetric method using a series of MG standards and a spectrophotometer [30].

\subsubsection{CSB Sorbent Dosage}

Thirty milliliters of MG solution ( $50 \mathrm{mg} / \mathrm{L}$ ) was agitated with various amount of the CSB (i.e., $0.025,0.050,0.100,0.500$ and $1.000 \mathrm{~g})$. The solutions were shaken at $100 \mathrm{rpm}$ for 120 minutes using a Multi-Function Rotator.

\subsubsection{Contact Time}

Thirty milliliters of MG solution $(50 \mathrm{mg} / \mathrm{L})$ was agitated with $0.050 \mathrm{~g}$ CSB at $100 \mathrm{rpm}$ using a Multi-Function Rotator at 6 contact times (i.e., 10, 20, 30, 40, 50 and 60 minutes).

\subsubsection{MG Solution pH}

Thirty milliliters of MG solution (50 mg/L) was agitated with $0.050 \mathrm{~g} \mathrm{CSB}$ at $100 \mathrm{rpm}$ for 10 minutes, using a Multi-Function Rotator at various initial $\mathrm{pH}$ of the MG solutions (i.e., 3, 4, 5, $6,7,8,9)$. The solution $\mathrm{pH}$ was adjusted using $0.1 \mathrm{M}$ sulfuric acid $\left(\mathrm{H}_{2} \mathrm{SO}_{4}\right)$ and 0.1 sodium hydroxide $(\mathrm{NaOH})$.

\subsection{Sorption Kinetic and Isotherm}

For sorption isotherm experiment, the $\mathrm{MG}$ stock solution $(100 \mathrm{mg} / \mathrm{L})$ was diluted into 5 concentrations (i.e., 100, 150, 200, 250 and $300 \mathrm{mg} / \mathrm{L}$ ). The diluted MG solutions were agitated with $0.050 \mathrm{~g} \mathrm{CSB}$ at $100 \mathrm{rpm}$ for 10 minutes, using a Multi-Function Rotator. The sorption data for contact time optimization was analyzed with linearized kinetic models (i.e., pseudo-first-order and pseudo-second-order) and the sorption isotherm data was analyzed with Langmuir and Freundlich models (Table 5). Malachite green removal percentage (\%) and sorption capacity, $\mathrm{q}_{\mathrm{t}}(\mathrm{mg} / \mathrm{g})$ for CSB were calculated using Equation (1) and (2) respectively.

$$
\begin{aligned}
& \text { Re moval\% } \%=\frac{[M G]_{i}-[M G]_{f}}{[M G]_{i}} \times 100 \\
& q_{t}=\frac{[M G]_{i}-[M G]_{f}}{m_{C S B}} \times V_{M G}
\end{aligned}
$$


Table 5.Linearized kinetic models (pseudo-first-order andpseudo-second-order) and isotherm models (Langmuir andFreundlich)

\begin{tabular}{cc}
\hline Kinetic/Isotherm Models & Linearized Equation \\
\hline Pseudo-first-order & $\log \left(q_{e}-q_{t}\right)=\log q_{e}-\frac{k_{1} t}{2.303}$ \\
Pseudo-second-order & $\frac{t}{q_{t}}=\frac{1}{k_{2} q_{e}^{2}}+\left(\frac{1}{q_{e}}\right) t$ \\
Langmuir & $\frac{C_{e}}{q_{e}}=\frac{C_{e}}{q_{\max }}+\frac{1}{K_{L} q_{\max }}$
\end{tabular}

Freundlich

$$
\ln q_{e}=\frac{1}{n}\left(\ln C_{e}\right)+\ln K_{F}
$$

where $[M G]_{i}$ and $[M G]_{f}$ are the initial and final concentrations for $M G(m g / L)$ respectively, $\mathrm{m}_{\mathrm{CSB}}$ is the mass for $\mathrm{CSB}(\mathrm{g})$; $\mathrm{V}_{\mathrm{MG}}$ is the volume for $\mathrm{MG}$ solution $(\mathrm{L}), \mathrm{t}$ is the contact time between CSB and MG solution (minute), $\mathrm{q}_{\mathrm{e}}$ is the equilibrium sorption capacity $(\mathrm{mg} / \mathrm{g}), \mathrm{k}_{1}\left(\mathrm{~min}^{-1}\right)$ and $\mathrm{k}_{2}(\mathrm{~g} / \mathrm{mg} \min )$ are the rate constant for the pseudo-first-order and pseudo-second-order equation respectively. The parameters for the pseudo-first-order and pseudo-second-order kinetic models were obtained by the linear regression of the $\log \left(\mathrm{q}_{\mathrm{e}}-\mathrm{q}_{\mathrm{t}}\right)$ versus $t$ plot and $t / q_{t}$ versus $t$ plot respectively. $q_{\max }$ is the maximum sorption capacity of CSB in the Langmuir model $(\mathrm{mg} / \mathrm{g}), \mathrm{n}$ is the empirical constant for Freundlich model $(\mathrm{L} / \mathrm{mg}), \mathrm{K}_{\mathrm{L}}$ and $\mathrm{K}_{\mathrm{F}}$ are the constants for Langmuir $(\mathrm{L} / \mathrm{mg})$, Freundlich $(\mathrm{mg} / \mathrm{g})$ respectively. The parameters for Langmuir isotherm model were obtained by linear regression of the $\mathrm{C}_{\mathrm{e}} / \mathrm{q}_{\mathrm{e}}$ versus $C_{e}$ and $\ln q_{e}$ versus $\ln C_{e}$ plots respectively. The separation factor $\left(R_{L}\right)$ was determined with Equation (3).

$$
R_{L}=\frac{1}{1+K_{L} C_{o}}
$$

The $R_{L}$ value indicates whether the sorption is either unfavourable $\left(R_{L}>1\right)$, linear $\left(R_{L}=1\right)$, favourable $\left(0<\mathrm{R}_{\mathrm{L}}<1\right)$ or irreversible $\left(\mathrm{R}_{\mathrm{L}}=0\right)$ [31]. The $\mathrm{R}_{\mathrm{L}}$ value 


\section{CONCLUSION}

There is potential in using CS for producing CSB for removing MG from aqueous solution. Sorption of MG by CSB is optimized at sorbent dosage of $1.67 \mathrm{~g} / \mathrm{L}$, contact time of 10 minutes and MG solution at $>\mathrm{pH}$ 7.4. Linear regression of the batch sorption data with kinetic and isotherm models indicated that $\mathrm{MG}$ molecules may have formed monolayer, and chemically bound to the homogenous surface of CSB. The Langmuir sorption capacity of CSB is lower to other biomass, but may offer greater stability when being regenerated to reuse. Further studies on the desorption behaviour of MG from CSB, and MG sorption performance by CSB in actual wastewater is needed to understand the potentials of CSB as sorbent for MG from polluted wastewater.

\section{ACKNOWLEDGEMENTS}

The authors would like to thank the UniversitiTeknologi MARA for financially supporting this research project through the LESTARI Research Grant [600-IRMI/MYRA 5/3/LESTARI(0117/2016)] and for providing research facility.

\section{REFERENCES}

[1] Ozdemir O, Turan M, Turan A Z, Faki A, Engin A B. Feasibility analysis of color removal from textile dyeing wastewater in a fixed-bed column system by surfactant-modified zeolite (SMZ). Journal of Hazardous Materials, 2009, 166(2):647-654

[2] Srivastava S, Sinha R, Roy D. Toxicological effects of malachite green. Aquatic Toxicology, 2004, 66(3):319-329

[3] Rangabhashiyam S, Anu N, Selvaraju N. Sequestration of dye from textile industry wastewater using agricultural waste products as adsorbents. Journal of Environmental Chemical Engineering, 2013, 1(4):629-641

[4] Jain A, Gupta V, Bhatnagar A. Utilization of industrial waste products as adsorbents for the removal of dyes. Journal of Hazardous Materials, 2003, 101(1):31-42

[5] Thimmaraju R, Bhagyalakshmi N, Narayan M, Ravishankar G A. Kinetics of pigment release from hairy root cultures of Beta vulgaris under the influence of $\mathrm{pH}$, sonication, temperature and oxygen stress. Process Biochemistry, 2003, 38(7):1069-1076 
[6] Enders A, Hanley K, Whitman T, Joseph S, Lehmann J. Characterization of biochars to evaluate recalcitrance and agronomic performance. Bioresource Technology, 2012, 114:644-653

[7] Wei M, Zhu W, Xie G, Lestander T A, Xiong S. Cassava stem wastes as potential feedstock for fuel ethanol production: A basic parameter study. Renewable Energy, 2015, $83: 970-978$

[8] Pattiya A. Thermochemical characterization of agricultural wastes from Thai cassava plantations. Energy Sources, Part A: Recovery, Utilization, and Environmental Effects, 2011, 33(8):691-701

[9] Budai A, Zimmerman A, Cowie A, Webber J, Singh B, Glaser B, Masiello C, Andersson D, Shields F, Lehmann J Biochar carbon stability test method: An assessment of methods to determine biochar carbon stability. Carbon Methodology, IBI Document, 2013

[10] Angın D, Şensöz S. Effect of pyrolysis temperature on chemical and surface properties of biochar of rapeseed (Brassica napus L.). International Journal of Phytoremediation, 2014, 16(7-8):684-693

[11] Saha P, Chowdhury S, Gupta S, Kumar I. Insight into adsorption equilibrium, kinetics and thermodynamics of Malachite Green onto clayey soil of Indian origin. Chemical Engineering Journal, 2010, 165(3):874-882

[12] Garg V, Kumar R, Gupta R. Removal of malachite green dye from aqueous solution by adsorption using agro-industry waste: a case study of Prosopis cineraria. Dyes and Pigments, 2004, 62(1):1-10

[13] Zhang J, Li Y, Zhang C, Jing Y. Adsorption of Malachite Green from aqueous solution onto carbon prepared from Arundo donax root. Journal of Hazardous Materials, 2008, 150(3):774-782

[14] Namasivayam C, Kavitha D. Removal of Congo Red from water by adsorption onto activated carbon prepared from coir pith, an agricultural solid waste. Dyes and Pigments, 2002, 54(1):47-58

[15] Porkodi K, Kumar K V. Equilibrium, kinetics and mechanism modeling and simulation of basic and acid dyes sorption onto jute fiber carbon: Eosin Yellow, Malachite Green and Crystal Violet single component systems. Journal of Hazardous Materials, 2007, 
143(1):311-327

[16] Crini G, Peindy H N, Gimbert F, Robert C. Removal of CI Basic Green 4 (Malachite Green) from aqueous solutions by adsorption using cyclodextrin-based adsorbent: Kinetic and equilibrium studies. Separation and Purification Technology, 2007, 53(1):97-110

[17] Garg V, Gupta R, Yadav A B, Kumar R. Dye removal from aqueous solution by adsorption on treated sawdust. Bioresource Technology, 2003, 89(2):121-124

[18] Cuong N M, Ishizaka S, Kitamura N. Donnan electric potential dependence of intraparticle diffusion of Malachite Green in single cation exchange resin particles: A laser trapping-microspectroscopy study. American Journal of Analytical Chemistry, 2012, 3(3):188-194

[19] Vasanth Kumar K, Ramamurthi V, Sivanesan S. Biosorption of Malachite Green, a cationic dye onto Pithophora sp., a fresh water algae. Dyes and Pigments, 2006, 69(1-2):102-107

[20] Ho Y S, McKay G. Pseudo-second order model for sorption processes. Process Biochemistry, 1999, 34(5):451-465

[21] Bulut Y, Aydin H. A kinetics and thermodynamics study of methylene blue adsorption on wheat shells. Desalination, 2006, 194(1):259-267

[22] Wang P, Cao M, Wang C, Ao Y, Hou J, Qian J. Kinetics and thermodynamics of adsorption of Methylene Blue by a magnetic graphene-carbon nanotube composite. Applied Surface Science, 2014, 290:116-124

[23] Mall I D, Srivastava V C, Agarwal N K, Mishra I M. Adsorptive removal of malachite green dye from aqueous solution by bagasse fly ash and activated carbon-kinetic study and equilibrium isotherm analyses. Colloids and Surfaces A: Physicochemical and Engineering Aspects, 2005, 264(1-3):17-28

[24] Dahri M K, Kooh M R R, Lim L B L. Water remediation using low cost adsorbent walnut shell for removal of malachite green: Equilibrium, kinetics, thermodynamic and regeneration studies. Journal of Environmental Chemical Engineering, 2014, 2(3):1434-1444

[25] Hameed B H, El-Khaiary M I. Batch removal of Malachite Green from aqueous solutions by adsorption on oil palm trunk fibre: Equilibrium isotherms and kinetic studies. Journal of Hazardous Materials, 2008, 154(1-3):237-244 
[26] Dahri M K, Kooh M R R, Lim L B L. Application of Casuarina equisetifolia needle for the removal of methylene blue and malachite green dyes from aqueous solution. Alexandria Engineering Journal, 2015, 54(4):1253-1263

[27] Tang H, Zhou W, Zhang L. Adsorption isotherms and kinetics studies of Malachite Green on chitin hydrogels. Journal of Hazardous Materials, 2012, 209:218-225

[28] Prapagdee S, Piyatiratitivorakul S, Petsom A, Tawinteung N. Application of biochar for enhancing cadmium and zinc phytostabilization in Vigna radiata L. cultivation. Water, Air, and Soil Pollution, 2014, 225(12):1-13

[29] Moriana R, Vilaplana F, Karlsson S, Ribes A. Correlation of chemical, structural and thermal properties of natural fibres for their sustainable exploitation. Carbohydrate Polymers, 2014, 112:422-431

[30] Low L W, Teng T T, Rafatullah M, Morad N, Azahari B. Adsorption studies of Methylene Blue and Malachite Green from aqueous solutions by pretreated lignocellulosic materials. Separation Science and Technology, 2013, 48(11):1688-1698

[31] Mckay G, Blair H, Gardner J. Adsorption of dyes on chitin. I. Equilibrium studies. Journal of Applied Polymer Science, 1982, 27(8):3043-3057

\section{How to cite this article:}

Yong S K, Mohamad Zaid K Z, Jamion N A, and Omar Q. Sorption of Malachite Green (MG) by Cassava Stem Biochar (CSB): kinetic and isotherm studies. J. Fundam. Appl. Sci., 2017, 9(6S), 273-287. 